\title{
PERSONAL LEARNING ENVIRONMENT OF THE TALENTED STUDENT - BASED ON THEIR OWN EXPERIENCES
}

\author{
ANETA KAMIŃSKA \\ Ignatianum Academy in Kraków, \\ Kopernika 26, 31-501 Kraków \\ E-mail address: anetakaminska.ignatianum@wp.pl \\ ORCID numer: 0000-0002-4612-6464
}

\begin{abstract}
Aim. The purpose of the research is to depict how talented students create their personal learning environment. The author of that paper shows a difference that has occurred thanks to the comparison between the manner in which average students and talented students build their personal learning environment.

Methods. The author has conducted quantitative research, by making a survey. The surveys were carried out among fifty talented students. This paper focuses on the presentation of their opinions. The respondents presented how they constructed their personal learning environment. Additionally, they expressed their viewpoints about their digital competences.

Results. The analysis shows that talented students are familiar with the latest digital tools. It allows them to design their personal learning space effectively. They can collect and process information profitably. They are also keen to share their knowledge with other participants of an educational process via the Internet, using some complex and practical devices. Moreover, talented students prefer discussing educational problems with other students online. They use some appropriate tools, such as chat rooms and social networking services. According to the research, the author can conclude that talented students are able to build and improve their digital learning space very well. They seem to create their personal learning environment functionally and consciously.

Conclusions. Talented learners use advanced searching strategies, methods of collecting and storing information, and also teamwork tools. It is particular that they are autonomous learners but they also like sharing knowledge with other learners. The level of information competences of the talented students is quite high.

Key words: personal learning environment, digital learning environment, information and communication technologies, talented learners, personalized learning environment
\end{abstract}




\section{INTRODUCTION}

$\mathrm{N}$ owadays, one can observe the rapid development of information and communication technologies in many areas of human life, including education. Moreover, the role of informal education is increasing. Modern education requires students to use sophisticated tools and understand comprehensive data. The development of information and communication technologies is an undeniable fact and it has a great impact on the environment of learning. Students have to meet the challenge of proper usage of them for their advancement. However, some people are reluctant towards developing their information and communication technologies skills, because they might not appreciate their value or learning how to use them properly is too demanding. Others abuse information and communication technologies and become addicted to them, which may lead to their isolation. The best way to use them is a deliberate and consistent choice of their usefulness. Moreover, it is important not to become overwhelmed by these technologies.

Firstly, the author describes the concept of a Personal Learning Environment (PLE). It is a complete learning space with a collection of tools that facilitate the learning process. The learners create their personal learning environment more or less consciously. Some of them built it in a quite sophisticated way. However, its shape is dynamic and it depends on many important factors, such as the level of the user's creativity, time he/she devotes to do it, a constant access to digital resources, a particular interest in them, and so on. The author underlines the finding that the process of constructing of personal learning environment is very personal.

The concept of a personal learning environment reveals that students create their learning environment according to their personal perspective and that they learn from different contexts, situations and interactions, which make their education much more informal and less controlled but also more interesting for them and other participants of the educational process. PLE also facilitates cooperation with other learners in building a social contact network management system (Kompen, Edirisingha, \& Monqquet 2009).

Furthermore, the author has chosen a broader sense of personal learning environment for this paper. It means that it is not only a specific tool or the set of tools, as a particular network service or a platform that makes the process of gathering and sharing knowledge with other learners easier and more effective, but it can be considered as a broad concept that organizes different technologies and services, especially Web 2.0 (Kamińska, \& Pulak, 2014).

To conclude, a personal learning environment is an individual, digital learning conception and formation that connects the needs, preferences, and experiences of the owners and that helps them to improve communication with other learners and construct comprehensive knowledge together.

Moreover, it is an essential task to show who talented learners are, to find out fully their considerable potential and notice how they constitute their personal learning environment. First of all, the talented learners are much more 
independent than the average students. They are interested in a field of knowledge or an issue very much and are able to search for information themselves with pleasure and determination, using many information resources such as the Internet, books, textbooks and so on, and asking specialists about their opinions (Hymer, \& Deborah,2017).

The talented student usually learns actively. He/She often has excellent memory, uses rich vocabulary, and thinks logically. Besides, the talented learner goes through a process of analysis and synthesis of data effectively. He/She makes some new, interesting and brilliant ideas (Davis, \& Rimm, 2014). He/ She has already acquired considerable knowledge of a field that he/she is interested in. He/She is an expert. Many talented learners are natural, charismatic and inspiring leaders. They motivate other learners to work and study together. However, some talented students are isolated. They prefer studying on their own.

The talented students are much more creative than average students. They can decide to obtain some goals, sometimes great and spectacular, and they are able to strive and get them. Moreover, they show possibilities of advanced achievements in the field of mental, creative, artistic or in particular subjects or non-standard scientific areas. They have their own opinions on many matters and they can defend them. They can undermine and challenge the opinion of others to call some existing solutions into questions. They can be unconventional and original in their proceedings.

Many talented students read many books and they are curious about the world around them very much. Some of them are sensitive and emphatic. Moreover, they can show abstract reasoning, in it on the high level, the ability to observe, analyze and synthesize phenomenon.

In terms of motivation, a gifted student may have the desire to deal with a specific issue, explore it for a long time maintaining curiosity, joy, and contentment.

Summarizing, talented learners differ from average and weak learners, mostly in social and emotional dimensions, while their cognitive skills might be comparable. Most of them are intelligent (represent high IQ). They can think reasonably. Moreover, they are self-sufficient and persistent learners who can become involved in an activity they like. They also might be better prepared for using tools of information and communication technologies and strategies to create a personal learning environment more effectively.

\section{METHODOLOGY}

As for the research of the creation of the personal learning environment of talented students, there is a gap. There are no studies like that. The research shows an interesting, unique and specific way that talented students build their personal learning environment. The purpose of that research is to depict how talented students create their personal learning environment, to establish in what degree they use online space. Nowadays, information and communication skills are very important for modern information users. The Internet is one of 
the most important sources of information, many people are immersed in this space that might be also called "social-information space." Consequently, it is very interesting how the talented students can manage to build their personal learning environment because it is one of the most necessary conditions to develop their talents. That's why the main purpose of this study was to identify:

How do talented learners organize their personal learning environment?

The research allows for answering the following specific questions:

1. What strategies do talented learners use to get information?

2. How do talented students systematize the information in the digital space that they have obtained?

3. How do they cooperate with other learners to build their digital learning space?

The author has conducted quantitative research, by making a survey. The questionnaire of this research was in a paper form. The author conducting that research has been inspired by the survey of her previous research, in which she was a co-author (Kamińska, \& Pulak, 2014), but the survey has been modified. She wanted to continue her research because she wanted to compare the results obtained by the average students and talented students.

\section{THE RESULTS}

The author studied the research material connected to information searching strategies, the methods of acquiring and storing information, the ways of systematising the educational components in digital space, the ways of cooperation and communication with other learners and participants of educational process and made some significant conclusions that might be interesting for the educationalists.

The detail description of the research group is presented in Table 1.

Table 1.

Characteristics of survey respondents

\begin{tabular}{|l|c|c|}
\hline \multicolumn{1}{|c|}{ Category } & $n$ & $\%$ \\
\hline Women & 37 & 74 \\
\hline Men & 23 & 46 \\
\hline Full-time/master studies & 21 & 42 \\
\hline Part-time/master studies & 0 & 0 \\
\hline Full-time/ bachelor studies & 29 & 58 \\
\hline Part-time/bachelor studies & 0 & 0 \\
\hline Originally from cities & 41 & 82 \\
\hline Originally from small towns/villages & 9 & 18 \\
\hline High scores obtained at the Matura exam 95\%-100\% (all subjects) & 50 & 100 \\
\hline Study at prestigious universities in Poland and abroad & 50 & 100 \\
\hline
\end{tabular}

Source: own study

Explanation: number of respondents $=\mathrm{n}$ 
The group consists of 50 successful students of prestigious universities who obtained high scores at most their Matura exams (95-1000\%) and were awarded by the foundation "Always Worth" from Cracow. Most of them are women $-74 \%$, but there are also some men $-46 \%$. Most of them originally come from big cities of Poland (such as Gdańsk, Kraków, Wrocław, and other big cities of Poland). They are 20-24 years old and they are studying full-time, master studies at the moment. The group of 50 respondents might not be considered a big group, but one should remember that there are not many talented people (elitist approach) in each country.

An important part of learning process is a search for information. How talented learners do it shows Table 2.

Table 2.

Information searching strategies mostly used in personal learning process $(n=50)$

\begin{tabular}{|c|c|c|c|c|c|c|c|c|}
\hline \multirow[t]{2}{*}{$\begin{array}{l}\text { Methods of searching } \\
\text { for information }\end{array}$} & \multicolumn{2}{|c|}{$\begin{array}{l}\text { Very } \\
\text { often }\end{array}$} & \multicolumn{2}{|c|}{ Often } & \multicolumn{2}{|c|}{ Rarely } & \multicolumn{2}{|c|}{ Never } \\
\hline & $n$ & $\%$ & $n$ & $\%$ & $n$ & $\%$ & $n$ & $\%$ \\
\hline Popular search engine, e.g. Google, Bing & 12 & 24 & 28 & 56 & 7 & 14 & 3 & 6 \\
\hline Printed materials, books and textbooks & 32 & 64 & 15 & 30 & 2 & 4 & 1 & 2 \\
\hline Using the library (printed books) & 19 & 38 & 27 & 54 & 3 & 6 & 1 & 4 \\
\hline $\begin{array}{l}\text { Specialist search engines, e.g. Google Scholar, } \\
\text { Google Books }\end{array}$ & 33 & 66 & 11 & 22 & 4 & 8 & 2 & 4 \\
\hline Questions to teachers (specialists) and friends & 5 & 10 & 10 & 20 & 28 & 56 & 7 & 14 \\
\hline
\end{tabular}

Source: own study

Explanation: number of respondents $=\mathrm{n}$

According to the research, talented students usually use combined strategies, both digital and traditional ones, to obtain new information. Most of them work with printed materials, books and textbooks borrowed from libraries, and they also prefer using different digital resources. Moreover, other people are not the main support for them at their process of getting knowledge, even when they are specialists.

Moreover, it is important how talented learners collect information of the digital resources that presents Table 3 . 
Journal of Education Culture and Society No. 2_2019

Table 3. The methods of acquiring and storing information in an electronic form used by the respondents $(n=50)$

\begin{tabular}{|c|c|c|c|c|c|c|c|c|}
\hline \multirow[t]{2}{*}{ Collection method } & \multicolumn{2}{|c|}{$\begin{array}{l}\text { very } \\
\text { often }\end{array}$} & \multicolumn{2}{|c|}{ often } & \multicolumn{2}{|c|}{ rarely } & \multicolumn{2}{|c|}{ never } \\
\hline & $n$ & $\%$ & $n$ & $\%$ & $n$ & $\%$ & $n$ & $\%$ \\
\hline Tabs (favourite) in the research & 23 & 46 & 25 & 50 & 2 & 4 & 0 & 0 \\
\hline Saving a copy of the web page to hard drive & 30 & 60 & 15 & 30 & 4 & 8 & 1 & 2 \\
\hline Social bookmarking services & 14 & 28 & 21 & 42 & 10 & 20 & 5 & 10 \\
\hline Photos (of books, diagrams etc. & 19 & 38 & 26 & 52 & 3 & 6 & 2 & 2 \\
\hline $\begin{array}{l}\text { Text notes edited on notebook, tablet, } \\
\text { smartphone }\end{array}$ & 4 & 8 & 32 & 64 & 6 & 12 & 8 & 16 \\
\hline Digital notebooks (Microsoft OneNote type) & 18 & 36 & 15 & 30 & 13 & 26 & 4 & 8 \\
\hline Playlist (audiovisual materials) & 14 & 28 & 27 & 54 & 8 & 16 & 1 & 2 \\
\hline Recordings (voice recorder, mobile) & 9 & 18 & 18 & 36 & 16 & 32 & 7 & 14 \\
\hline Mind maps (Mind map software) & 12 & 24 & 10 & 2 & 13 & 26 & 15 & 30 \\
\hline
\end{tabular}

Source: own study

Explanation: number of respondents $=\mathrm{n}$

The respondents use diverse methods of gaining and storing information in an electronic form. Tabs in the research, saving a copy of the web page to hard drive or digital notebooks facilitate their personal learning environment. They also collect and process pictures and data making photos of books and text notes edited on notebooks, tablets etc. Some of them use playlists (audiovisual materials), mind maps (Mind map software) or make recordings (voice recorder, mobile).

Competent management of own resources of a user in electronic form is also a very important skill. It is a huge problem to obtain information but it might be a challenge to organize and categorize it that shows Table 4.

Table 4.

The ways of systematising the educational components in digital space $(\mathrm{n}=50)$

\begin{tabular}{|c|c|c|c|c|c|c|c|c|}
\hline \multirow[t]{2}{*}{ Collection method } & \multicolumn{2}{|c|}{$\begin{array}{l}\text { very } \\
\text { often }\end{array}$} & \multicolumn{2}{|c|}{ often } & \multicolumn{2}{|c|}{ rarely } & \multicolumn{2}{|c|}{ never } \\
\hline & $n$ & $\%$ & $n$ & $\%$ & $n$ & $\%$ & $n$ & $\%$ \\
\hline $\begin{array}{l}\text { Keeping thematic folders (on hard disks and } \\
\text { pendrives) }\end{array}$ & 43 & 86 & 7 & 14 & 0 & 0 & 0 & 0 \\
\hline Keeping thematic folders in tabs (favourites) & 16 & 32 & 25 & 50 & 9 & 18 & 0 & 0 \\
\hline $\begin{array}{l}\text { Descriptions of links to websites by means } \\
\text { of tags }\end{array}$ & 19 & 38 & 28 & 56 & 2 & 4 & 1 & 2 \\
\hline $\begin{array}{l}\text { Using the program of bibliographical data } \\
\text { management (e.g. ZOTERO) }\end{array}$ & 17 & 34 & 22 & 44 & 10 & 20 & 1 & 2 \\
\hline
\end{tabular}

Source: own study

Explanation: number of respondents $=\mathrm{n}$ 
Table 4 reveals that talented students are familiar with different methods of organizing materials in digital environment. Most of them keep thematic folders. They also know how to use the program of bibliographical data management that is a very useful tool at the level of academic education.

However, networking with other participants of the education process of the respondents presents Table 5.

\section{Table 5.}

The ways of cooperation and communication with other learners and participants of educational process $(n=50)$

\begin{tabular}{|l|c|c|c|c|c|c|c|c|}
\hline \multirow{2}{*}{ Collection method } & \multicolumn{2}{|c|}{$\begin{array}{c}\text { Very } \\
\text { often }\end{array}$} & \multicolumn{2}{c|}{ often } & \multicolumn{2}{c|}{ rarely } & \multicolumn{2}{c|}{ never } \\
\cline { 2 - 12 } & $n$ & $\%$ & $n$ & $\%$ & $n$ & $\%$ & $n$ & $\%$ \\
\hline E-mails to friends & 9 & 18 & 12 & 24 & 24 & 48 & 5 & 10 \\
\hline $\begin{array}{l}\text { Group e-mails (one e-mail address for } \\
\text { whole team) }\end{array}$ & 14 & 28 & 16 & 32 & 12 & 24 & 8 & 16 \\
\hline A discussion forum & 21 & 42 & 22 & 44 & 4 & 8 & 3 & 6 \\
\hline $\begin{array}{l}\text { Facebook or other social networking } \\
\text { services }\end{array}$ & 38 & 76 & 11 & 22 & 1 & 2 & 0 & 0 \\
\hline $\begin{array}{l}\text { Teamwork tools and Cloud Computing } \\
\text { (e.g. Google Drive, Dropbox) }\end{array}$ & 19 & 38 & 15 & 30 & 10 & 20 & 6 & 12 \\
\hline
\end{tabular}

Source: own study

Explanation: number of respondents $=\mathrm{n}$

The Table 5 reveals that most respondents, 38 people $(76 \%)$ use Facebook or other social networking services, a discussion forum 21 (42\%) or teamwork tools and Cloud Computing (e.g. Google Drive, Dropbox) - 19 people 38\%) to communicate with other people. They send e-mails to friends $9(18 \%)$ and group e-mails - 14 people $(28 \%)$ less.

Table 6.

The self-recognition of the digital competences of the talented students $(n=50)$

\begin{tabular}{|l|c|c|}
\hline \multicolumn{1}{|c|}{ The level of competence } & $n$ & $\%$ \\
\hline Basic & 35 & 70 \\
\hline Great & 15 & 30 \\
\hline Professional & 0 & 0 \\
\hline
\end{tabular}

Source: own study

Explanation: number of respondents $=\mathrm{n}$

Most talented students admit that their digital competences in creating a personal learning environment are at a basic level. Only fifteen respondents claim that they are good at it. They also said during the additional conversation with the author of the paper that they need some more exercises, experiences and knowledge about it. One should remember that most talented people are perfectionists and they want to improve their work and qualifications. 
Talented students declare that they benefit from different teamwork tools. The research revealed that they know such tools quite well. They do not send e-mails a lot, but they are keen on discussion forums and social networking services. They also work with Google Drive and Dropbox that are not the most popular among average students.

\section{CONCLUSIONS}

The research offered the answer to the research questions. To answer the main question, the research has revealed that talented students create their personal learning environment in individual and unique manners. They seem to be very independent learners, and they can get knowledge themselves without other people's help. Their digital skills are on a high level. They are better at building their personal learning environment than average students.

To answer the first detailed question - what methods and strategies do the talented learners use to get information? According to the research they operate with quite sophisticated and diverse searching strategies, methods of collecting and storing information, and also teamwork tools. Moreover, they use combined strategies, both digital and traditional, to get information. They use different methods that is convenient and makes them more skillful digital users.

The second specific question - how talented students systematize in the digital space the information that they have obtained, can be answer shortly that talented students keep digital information in a quite common way, using thematic folders. Fewer of them use more advanced programmes of data management.

As for the cooperation with other learners - that is connected to the third specific question, the talented learners like discussing their knowledge with other people, they are quite open to share their opinions with other learners via the Internet, especially when they can carry on dynamic conversations using discussion forums and social networking services.

Furthermore, the comparison between the ways that average students of pedagogy and the talented students build their personal learning environment indicates some significant differences. The students of pedagogy use basic strategies to obtain new data. Most of them go to the library to get it. Moreover, the use of advanced search tools was not popular among them. The level of information competences talented students maintained is much more sufficient. They benefit both from traditional and online resources to obtain knowledge. They use more sophisticated tools. Another difference has occurred in the social field. The talented students search for information on their own, but the average students of pedagogy ask teachers and friends for their opinions.

As for the methods of collecting and storing information in the electronic form, the students of pedagogy primarily use thematic folders and subfolders, but talented students know how to use even more complex programs of 
bibliographical data management, that provide them with knowledge on the academic level. Moreover, the communication of talented students with other participants in the educational process is more dynamic.

\section{REFERENCES}

1. Davis, G.A., Rimm, S.B. (2014). Education of the Gifted and Talented. Harlow: Pearson Education Limited.

2. Hymer, B., Deborah, M. (2017). Gifted and Talented Learners. Creative a Policy for Inclusion. New York: David Fulton Publishers.

3. Kamińska, A., Pulak, I. (2014). Knowledge organization in a digital learning environment in the experiences of pedagogy students. In: W. Babik (Ed.), Knowledge Organization in the 21th Century. Between Historical Patterns and Future Prospects (pp.532-539). Kraków: Ergon.

4. Kompen, R.T., Edirisingha, P., Monqquet, J.M. (2009). Using Web 2.0 Applications as Supporting Tools for Personal Learning Environment. In: M.D. Lytras (Ed.) Best Practices for the Knowledge Society. Knowledge, Learning, Development and technology for All (pp.33-44). Berlin Heidelberg: Springer. 